\title{
Corrigendum: Validation and Development of COI Metabarcoding Primers for Freshwater Macroinvertebrate Bioassessment
}

\section{OPEN ACCESS}

Edited and reviewed by:

Michael M. Douglas,

University of Western Australia,

Australia

*Correspondence:

Vasco Elbrecht

Vasco.Elbrecht@uni-due.de

Specialty section:

This article was submitted to

Freshwater Science,

a section of the journal

Frontiers in Environmental Science

Received: 04 May 2017

Accepted: 13 June 2017

Published: 23 June 2017

Citation:

Elbrecht $V$ and Leese F (2017)

Corrigendum: Validation and Development of COI Metabarcoding

Primers for Freshwater Macroinvertebrate Bioassessment.

Front. Environ. Sci. 5:38.

doi: 10.3389/fenvs.2017.00038

\author{
Vasco Elbrecht ${ }^{1 *}$ and Florian Leese ${ }^{1,2}$ \\ ${ }^{1}$ Aquatic Ecosystem Research, Faculty of Biology, University of Duisburg-Essen, Essen, Germany, ${ }^{2}$ Centre for Water and \\ Environmental Research, University of Duisburg-Essen, Essen, Germany
}

Keywords: DNA barcoding, primer development, primer evaluation, primer bias, ecosystem assessment, in silico PCR, invertebrates

\section{A corrigendum on}

Validation and Development of COI Metabarcoding Primers for Freshwater Macroinvertebrate Bioassessment

by Elbrecht, V., and Leese, F. (2017). Front. Environ. Sci. 5:11. doi: 10.3389/fenvs.2017.00011

In the original article, the reference for Bista et al. (2017) was incorrectly written as "Carvalho, G. R., Walsh, K., Seymour, M., Hajibabaei, M., Lallias, D., Christmas, M., et al. (2017). Annual time-series analysis of aqueous eDNA reveals ecologically relevant dynamics of lake ecosystem biodiversity. Nat. Commun. 8, 1-11. doi: 10.1038/ncomms14087." It should be "Bista, I., Carvalho, G. R., Walsh, K., Seymour, M., Hajibabaei, M., Lallias, D., et al. (2017). Annual time-series analysis of aqueous eDNA reveals ecologically relevant dynamics of lake ecosystem biodiversity. Nat. Commun. 8, 1-11. doi: 10.1038/ncomms14087."

In the original article, there was a mistake in Table 2 as published. "Ephemeroptera" and taxa abundance (8) are missing in the table. The corrected Table appears below. The authors apologize for this error and state that this does not change the scientific conclusions of the article in any way.

\section{REFERENCES}

Elbrecht, V., and Leese, F. (2015). Can DNA-based ecosystem assessments quantify species abundance? Testing primer bias and biomass-sequence relationships with an innovative metabarcoding protocol. PLoS ONE 10:e130324. doi: 10.1371/journal.pone.0130324

Elbrecht, V., Taberlet, P., Dejean, T., Valentini, A., Usseglio-Polatera, P., Beisel, J.-N., et al. (2016). Testing the potential of a ribosomal $16 \mathrm{~S}$ marker for DNA metabarcoding of insects. PeerJ 4, e1966-e1912. doi: 10.7717/peerj. 1966
Conflict of Interest Statement: The authors declare that the research was conducted in the absence of any commercial or financial relationships that could be construed as a potential conflict of interest.

Copyright (C) 2017 Elbrecht and Leese. This is an open-access article distributed under the terms of the Creative Commons Attribution License (CC BY). The use, distribution or reproduction in other forums is permitted, provided the original author(s) or licensor are credited and that the original publication in this journal is cited, in accordance with accepted academic practice. No use, distribution or reproduction is permitted which does not comply with these terms. 


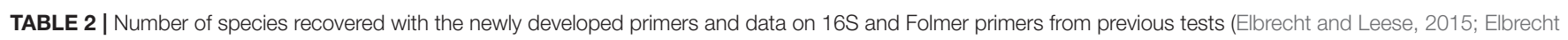
et al., 2016).

\begin{tabular}{|c|c|c|c|c|c|c|c|}
\hline \multirow[t]{2}{*}{ Taxonomic group } & \multirow[t]{2}{*}{ Number of specimens } & \multicolumn{6}{|c|}{ Number of specimens recovered with specific primer combination } \\
\hline & & LCO1490+HCO2198 & $16 S$ ins & BF2+BR2 & BF2+BR1 & $\mathrm{BF} 1+\mathrm{BR} 2$ & $\mathrm{BF} 1+\mathrm{BR} 1$ \\
\hline Ephemeroptera & 8 & $7(88 \%)$ & $8(100 \%)$ & $8(100 \%)$ & $8(100 \%)$ & $8(100 \%)$ & $8(100 \%)$ \\
\hline Plecoptera & 4 & $4(100 \%)$ & $4(100 \%)$ & $4(100 \%)$ & $4(100 \%)$ & $4(100 \%)$ & $4(100 \%)$ \\
\hline Trichoptera & 15 & $13(86 \%)$ & 15 (100\%) & 15 (100\%) & 15 (100\%) & 15 (100\%) & 15 (100\%) \\
\hline Diptera & 8 & $7(88 \%)$ & $7(88 \%)$ & $8(100 \%)$ & $8(100 \%)$ & $8(100 \%)$ & $8(100 \%)$ \\
\hline Other insects & 7 & $7(100 \%)$ & $7(100 \%)$ & $7(100 \%)$ & $7(100 \%)$ & $7(100 \%)$ & $6(86 \%)$ \\
\hline Other metazoa & 10 & $5(50 \%)$ & $2(20 \%)$ & 7 (70\%) & $6(60 \%)$ & $9(90 \%)$ & $6(60 \%)$ \\
\hline$\Sigma$ All insects & 42 & $38(91 \%)$ & $41(98 \%)$ & $42(100 \%)$ & $42(100 \%)$ & $42(100 \%)$ & $41(98 \%)$ \\
\hline $\mathrm{SD}^{\star}$ & & 1.01 & 0.62 & 0.54 & 0.65 & 0.71 & 0.84 \\
\hline Precision $^{\star \star}$ & & 0.72 & 0.37 & 0.28 & 0.35 & 0.49 & 0.58 \\
\hline$\Sigma$ All taxa & 52 & 43 (83\%) & 43 (83\%) & 49 (94\%) & 48 (92\%) & 51 (98\%) & 47 (90\%) \\
\hline
\end{tabular}

${ }^{\star}$ Mean standard deviation (SD) of $\log _{10}$ read abundance from each insect taxon that was detected (specimens with $<0.003 \%$ read abundance discarded).

${ }^{\star *}$ Precision defined as the $S D$ of the mean $\log _{10}$ distance to the expected read abundances, calculated for each morphotaxon (all taxa). 